University of Montana

ScholarWorks at University of Montana

$9-2008$

\title{
Weed-Biocontrol Insects Reduce Native-Plant Recruitment Through Second-Order Apparent Competition
}

Dean E. Pearson

Ragan M. Callaway

University of Montana - Missoula, Ray.Callaway@mso.umt.edu

Follow this and additional works at: https://scholarworks.umt.edu/biosci_pubs

Part of the Biology Commons

Let us know how access to this document benefits you.

\section{Recommended Citation}

Pearson, Dean E. and Callaway, Ragan M., "Weed-Biocontrol Insects Reduce Native-Plant Recruitment Through Second-Order Apparent Competition" (2008). Biological Sciences Faculty Publications. 256. https://scholarworks.umt.edu/biosci_pubs/256

This Article is brought to you for free and open access by the Biological Sciences at ScholarWorks at University of Montana. It has been accepted for inclusion in Biological Sciences Faculty Publications by an authorized administrator of ScholarWorks at University of Montana. For more information, please contact scholarworks@mso.umt.edu. 


\title{
WEED-BIOCONTROL INSECTS REDUCE NATIVE-PLANT RECRUITMENT THROUGH SECOND-ORDER APPARENT COMPETITION
}

\author{
Dean E. Pearson ${ }^{1,2,3}$ and Ragan M. Callaway ${ }^{2}$ \\ ${ }^{1}$ Rocky Mountain Research Station, USDA Forest Service, 800 E. Beckwith Avenue, Missoula, Montana 59801 USA \\ ${ }^{2}$ Division of Biological Sciences, University of Montana, Missoula, Montana 59812 USA
}

\begin{abstract}
Small-mammal seed predation is an important force structuring native-plant communities that may also influence exotic-plant invasions. In the intermountain West, deer mice (Peromyscus maniculatus) are prominent predators of native-plant seeds, but they avoid consuming seeds of certain widespread invasives like spotted knapweed (Centaurea maculosa). These mice also consume the biological-control insects Urophora spp. introduced to control $C$. maculosa, and this food resource substantially increases deer mouse populations. Thus, mice may play an important role in the invasion and management of $C$. maculosa through food-web interactions. We examined deer mouse seed predation and its effects on seedling emergence and establishment of a dominant native grass, Pseudoroegneria spicata, and forb, Balsamorhiza sagittata, in C. maculosa-invaded grasslands that were treated with herbicide to suppress $C$. maculosa or left untreated as controls. Deer mice readily took seeds of both native plants but removed 2-20 times more of the larger $B$. sagittata seeds than the smaller $P$. spicata seeds. Seed predation reduced emergence and establishment of both species but had greater impacts on B. sagittata. The intensity of seed predation corresponded with annual and seasonal changes in deer mouse abundance, suggesting that abundance largely determined mouse impacts on native-plant seeds. Accordingly, herbicide treatments that reduced mouse abundance by suppressing $C$. maculosa and its associated biocontrol food subsidies to mice also reduced seed predation and decreased the impact of deer mice on $B$. sagittata establishment. These results provide evidence that Urophora biocontrol agents may exacerbate the negative effects of $C$. maculosa on native plants through a form of second-order apparent competition - a biocontrol indirect effect that has not been previously documented. Herbicide suppressed C. maculosa and Urophora, reducing mouse populations and moderating seed predation on native plants, but the herbicide's direct negative effects on native forb seedlings overwhelmed the indirect positive effect of reducing deer mouse seed predation. By manipulating this four-level food chain, we illustrate that host-specific biological control agents may impact nontarget plant species through food-web interactions, and herbicides may influence management outcomes through indirect trophic interactions in addition to their direct effects on plants.
\end{abstract}

Key words: apparent competition; biological control; Centaurea maculosa; exotic plants; food-web interactions; herbicide; indirect effects; nontarget effects; Peromyscus maniculatus; seed predation; Urophora spp.; weed management.

\section{INTRODUCTION}

Consumer interactions can inhibit or facilitate biological invasions. The leading hypothesis posed to explain exotic invasions is enemy release - the idea that exotic species become invasive by escaping top-down control by coevolved natural enemies (Keane and Crawley 2002). Several studies provide support for this hypothesis by showing that exotic plants that experience the greatest release from natural enemies are among the most highly invasive (Klironomos 2002, Wolfe 2002, Torchin et al. 2003, Reinhart and Callaway 2004). However, generalist herbivores native to the incipient range can also effectively suppress exotic plants that

Manuscript received 26 October 2007; accepted 19 February 2008. Corresponding Editor: J. Belnap.

${ }^{3}$ E-mail: dpearson@fs.fed.us might otherwise become invasive (Parker et al. 2006). Thus, natural enemies may facilitate or inhibit invasion, but the mechanisms for these interactions are poorly understood, and consumer interactions are not well integrated into invasive-species management. The primary application of consumer ecology to invasivespecies management is classical biological control. In classical biological control a pest's natural enemies are introduced from its native range to its invaded range to suppress its populations (Keane and Crawley 2002). This method can be highly effective (Gurr and Wratten 2000), but it can also cause negative side effects to nontarget species (Follett and Duan 2000). For example, control agents can directly impact nontarget species when they do not restrict their attack to the target pest (Simberloff and Stiling 1996). Recognition of this risk has lead to screening for host-specific weed-biocontrol agents (McEvoy 1996). However, recent work shows 
that even host-specific biocontrol agents may have nontarget effects due to complex consumer interactions (Pearson and Callaway 2003, 2005), and little is known about how other prevalent management tools like broadleaf herbicides may interact with biological control and other consumer interactions to influence weedmanagement outcomes. For example, broadleaf herbicides are now widely used in natural areas to control exotic forbs (Rice and Toney 1998), and recent studies show that these herbicides may also result in complicated management outcomes such as shifting plant communities from forbs toward grasses and facilitating secondary invaders (Y. K. Ortega and D. E. Pearson, unpublished manuscript). Here, we examine how classical biological control and broadleaf herbicides interact with a strong consumer interaction, seed predation, to influence the outcome of weed management.

Small mammals are formidable consumers that can substantially influence the composition and structure of native-plant communities (Huntly and Inouye 1988, Brown and Heske 1990, Hulme 1996, Gutierrez et al. 1997, Ostfeld et al. 1997, Edwards and Crawley 1999, Manson et al. 2001, Seabloom and Richards 2003, Howe et al. 2006). Through selective herbivory and seed predation small mammals have been shown to strongly alter plant community composition, structure, and, potentially, ecosystem functions in grassland and shrubland systems by suppressing large-seeded and otherwisepreferred species (Brown and Heske 1990, Hulme 1996, Gutierrez et al. 1997, Edwards and Crawley 1999, Seabloom and Richards 2003, Howe et al. 2006). Because of the powerful effects they can have on plant communities, small mammals have great potential to influence exotic-plant invasions. For example, if small mammals fail to incorporate exotic plants into their diets, they could facilitate invasion by suppressing native but not exotic species (Manson and Stiles 1998, Vilà and D'Antonio 1998, Vilà and Gimeno 2003). On the other hand, if small-mammal consumers readily incorporate exotic plants into their diet, they could contribute to biotic resistance by suppressing invaders (Elton 1958, Parker et al. 2006). Conversely, small-mammal consumption of exotic plants could exacerbate negative effects of invaders on native plants through apparent competition if the exotic subsidizes consumer populations but is little affected by the consumer attack (Holt 1977, Noonburg and Byers 2005). Despite the importance of small-mammal consumers in native systems, we know little about how they may affect exotic-plant invasions and invasive-species management.

In western North America, spotted knapweed (Centaurea maculosa) is an exotic Eurasian forb that aggressively invades grasslands and savannas (Sheley et al. 1998) and dramatically reduces the abundance of many native plant species (Ridenour and Callaway 2001, Ortega and Pearson 2005). In the intermountain grasslands most severely impacted by $C$. maculosa invasions, deer mice (Peromyscus maniculatus) are the dominant small-mammal consumers (Pearson et al. 2000, 2001). Deer mice eat primarily invertebrates and seeds and can reduce plant populations through seed predation (Maron and Kauffman 2006). Importantly, deer mice readily consume native-plant seeds but appear to avoid ingesting $C$. maculosa seeds (Pearson et al. 2000). Therefore, deer mice have the potential to facilitate invasion of $C$. maculosa by suppressing the natives but not the invader. This situation is further complicated by management of C. maculosa using classical biological control and broadleaf herbicides.

Classical biological control of $C$. maculosa has resulted in the introduction of 13 species of exotic insects since the early 1970s (Lang et al. 2000). Although several agents have become well established, C. maculosa remains extremely abundant and continues to expand its range (Sheley et al. 1998). Due to the continued abundance of $C$. maculosa, biocontrol agents like the gall flies, Urophora affinis and U. quadrifaciata, have themselves become extremely abundant (Myers and Harris 1980), and Urophora now provide a rich food resource for many native consumers (Story et al. 1995). Peromyscus maniculatus is particularly adept at exploiting the abundant larvae of Urophora that overwinter from September to June within C. maculosa seedheads (Pearson et al. 2000). As a result, Urophora now provide a superabundant winter food subsidy that can elevate mouse populations 2-3 fold (Ortega et al. 2004, Pearson and Callaway 2006, Pearson and Fletcher 2008). Given deer mouse capacity as a seed predator, this scenario provides the potential for a form of tritrophic or secondorder apparent competition in which C. maculosa invasion may elevate seed predation on native plants by indirectly increasing deer mouse populations via Urophora biocontrol agents (Pearson and Callaway 2003).

Herbicide applications may further complicate these consumer interactions. Broadleaf herbicides, which suppress forbs, are commonly used to control exotic forbs like C. maculosa (Rice and Toney 1998, Pearson and Fletcher 2008; Y. K. Ortega and D. E. Pearson, unpublished manuscript). Previous work has established that the direct (nontrophic) effects of applying broadleaf herbicides such as picloram in $C$. maculosa-invaded grasslands include: (1) strong suppression of $C$. maculosa, (2) moderate suppression of mature native forbs, (3) strong suppression of native-forb seedlings, and (4) strong enhancement of native grasses (Rice and Toney 1998, Tyser et al. 1998; Y. K. Ortega and D. E. Pearson, unpublished manuscript). Broadleaf-herbicide applications can also result in indirect (trophic) effects. Prior research indicates that suppressing $C$. maculosa with broadleaf herbicides reduces $P$. maniculatus populations to pre-invasion levels by removing the $C$. maculosa biocontrol food subsidies to the mice (Pearson and Fletcher 2008). Therefore, additional indirect effects of herbicide treatments may include reductions in deer mouse seed predation on native plants, which may 


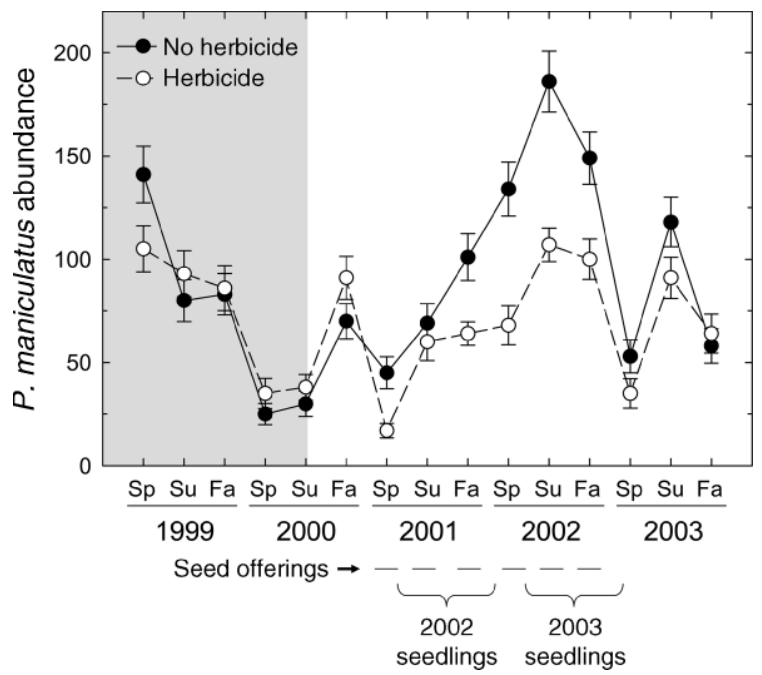

FIG. 1. Sampling periods for seed offerings and seed emergence and germination experiments overlaid with Peromyscus maniculatus population estimates (jackknife estimates, mean $\pm \mathrm{SE}$, by season). The shaded area represents the pretreatment period when $P$. maniculatus were sampled prior to herbicide applications in May 2000. Dashes below the figure indicate the discrete two-week periods when seed offerings were conducted. The $\sim 11$-month windows when seed-addition experiments took place are indicated: $\mathrm{Sp}=$ spring $($ MarchMay), $\mathrm{Su}=$ summer (June-August), $\mathrm{Fa}=$ fall (SeptemberNovember). The figure is modified from Pearson and Fletcher (2008: Fig. 4).

increase seedling establishment in native-plant populations.

To better understand how consumer interactions influence invasive-weed management, we examined the effects of $P$. maniculatus seed predation on seedling emergence and establishment of native plants in $C$. maculosa-invaded grasslands that were either treated with the broadleaf herbicide picloram or left untreated as controls. Our primary objective was to evaluate how broadleaf-herbicide treatment intended to control $C$. maculosa (and concurrently reduce the exotic biocontrol agents that subsidize mouse populations) affects $P$. maniculatus seed predation and its influence on nativeplant recruitment. We examined these impacts by quantifying the effects of seed predation on seedling emergence and establishment for two dominant nativeplant species, a large-seeded forb, arrowleaf balsamroot (Balsamorhiza sagittata; see Plate 1), and a smaller seeded grass, bluebunch wheatgrass (Pseudoroegneria spicata).

\section{Methods \\ Study area}

The study was conducted at the Calf Creek Wildlife Management Area, $\sim 10 \mathrm{~km}$ northeast of Hamilton in the foothills of the Sapphire Mountains in western Montana, USA. The study site is dominated by Palousetype grasslands (Lynche 1955, Mueggler and Stewart 1980) on rolling hills that are separated by conifer-lined drainages. Average annual precipitation is $\sim 32 \mathrm{~cm}$, coming mostly as snow during the winter and rain in May and June. Study plots were located in the grasslands and were dominated by Pseudoroegneria spicata and Koeleria macrantha (june grass), with scattered Artemisia tridentata (Great Basin sage). Balsamorhiza sagittata and Lupinus species are the dominant native forbs at the site. Prior to herbicide applications, Centaurea maculosa dominated the community, averaging $>50 \%$ cover across the study area (Pearson and Fletcher 2008).

\section{Overall sampling design}

Sampling was conducted at four replicate plots. Plots were selected so that they had similar vegetation and were located $500 \mathrm{~m}$ to $>1000 \mathrm{~m}$ apart. Within each plot we located three primary transects, each $220 \mathrm{~m}$ long, and parallel to each other and to the slope (Appendix). Transects were separated by $50 \mathrm{~m}$. Herbicide treatment was randomly assigned to half of each plot splitting transects in half, with large buffer strips on the sides. On 5 May 2000 the broadleaf-herbicide Tordon (picloram; Dow AgroScience, Indianapolis, Indiana, USA) was applied by helicopter at $1.24 \mathrm{~L} /$ ha to control $C$. maculosa. This is a standard application rate of this herbicide for C. maculosa management, and the study duration is consistent with the recommended reapplication interval of 3-5 years (Rice et al. 1997, Rice and Toney 1998). Centaurea maculosa exhibits a high degree of sensitivity to this herbicide, allowing effective removal of this plant with low dosages that minimize impacts on nontarget native forbs (Rice and Toney 1998). Urophora are also removed in this process as they are obligate parasites of C. maculosa.

To evaluate seed predation on native species, we chose the forb $B$. sagittata and the grass $P$. spicata because they are community dominants that produce some of the largest seeds within their corresponding functional groups (individual seed mass is $0.0024 \mathrm{~g}$ for $P$. spicata and $0.0080 \mathrm{~g}$ for $B$. sagittata) and therefore should be especially susceptible to small-mammal seed predation (e.g., Brown and Heske 1990, Hulme 1994a, Garb et al. 2000). Additionally, these species are two of the natives most significantly negatively impacted by $C$. maculosa invasion (Ortega and Pearson 2005), and the grass is positively affected by broadleaf herbicide whereas the forb is negatively affected (Y. K. Ortega and D. E. Pearson, unpublished manuscript). Seed removal and seedling-emergence experiments were conducted from 2001 to 2004 after herbicide applications. Peromyscus maniculatus populations were sampled along the primary transects during spring, summer, and fall, 1999-2003 as described in detail in Pearson and Fletcher (2008). Certain indices of deer mouse abundance were used as covariates in analyses as described below (see Data analysis), and overall trends in mouse abundance are presented in Fig. 1 as they are fundamental for interpreting our results. Mean home-range size for $P$. 
maniculatus in xeric habitats is $\sim 0.11$ ha (Bowers and Smith 1979). Relatively little movement of mice was noted across the treatment boundaries (Pearson and Fletcher 2008). Detailed results regarding the deer mouse response to herbicide treatment are reported by Pearson and Fletcher (2008).

\section{Seed removal}

We used seed offerings to index mouse seed predation on the two plant species in the two herbicide treatments over time. We placed B. sagittata and P. spicata seeds in wire cages designed to allow predation by deer mice, but to exclude all other potential predators. We placed seeds in 57-mL plastic cups set within similar cups that were glued to plywood surfaces $(45 \times 45 \times 0.6 \mathrm{~cm})$ and covered by wire-mesh cages $(25 \mathrm{~cm}$ on sides, $15 \mathrm{~cm}$ tall; mesh size $0.5 \mathrm{~cm}$ ). Cages had two small entrances $5 \mathrm{~cm}$ wide by $3.5 \mathrm{~cm}$ tall cut in all four sides to provide mice access, but prevent birds, larger rodents, and other mammals from reaching the seeds. The only other small mammals we captured at the study areas during seed experiments were rare Preble's shrews (Sorex preblei), which are insectivores, and montane voles (Microtus montanus), herbivores that primarily eat plant leaves and shoots, and that comprised $<2 \%$ of the captures (Pearson and Fletcher 2008). A sticky layer of Tanglefoot (Tanglefoot Company, Grand Rapids, Michigan, USA) was painted around the bases of the fastened plastic cups to prevent insects from removing seeds. Neither experimental species has elaiosomes, reducing the potential for myrmecochory. The seed-removal cages were located every $30 \mathrm{~m}$ along the primary transects with the innermost stations starting $10 \mathrm{~m}$ from the treatment boundary (Appendix). This resulted in four stations per transect on each side of the treatment boundary and 24 stations per plot.

We conducted seed-removal experiments in the spring, summer, and fall of 2001 and 2002 (Fig. 1). Seed offerings were split into two periods (first and second weeks) with each species of seed randomly assigned to either the first or second period on each plot in each season. Seed offerings consisted of $10.00 \pm$ $0.01 \mathrm{~g}$ dry mass of seeds per station (mean $\pm \mathrm{SD}$ ). Dry mass was measured on an electronic triple-beam scale after air drying seeds at $\sim 27^{\circ} \mathrm{C}$ and reweighing seeds daily until seed masses stabilized. Seed offerings were replaced after two days in the cages and offerings and cages were removed on the fourth day, resulting in a total of two two-day seed offerings during each oneweek sample period. Pilot studies suggested that such offerings would generally exceed $P$. maniculatus removal rates at the mouse densities we have measured in the field (D. E. Pearson, unpublished data), thus ensuring that some seeds would remain for weighing after each two-day interval. Seeds remaining in cups at the end of each two-day period were collected, air dried as described above, and weighed. The resulting masses were subtracted from the initial masses to determine seed-removal rates per two-day interval and removal rates from the two two-day intervals were summed for each one-week sample period. Data were not included if cages showed signs of disturbance from sources other than mice.

\section{Seedling emergence and establishment}

To examine the effect of granivory on $B$. sagittata and $P$. spicata establishment, we set out seeds of each species and compared seedling emergence and establishment rates in cage treatments with (1) no predation (all small mammals, birds, and insects excluded; seeds added), (2) $P$. maniculatus-only predation (birds, insects, and small mammals larger than $P$. maniculatus excluded; seeds added), and (3) controls: treatments that controlled for cage effects and effects of natural seed rain and seed banks ( $P$. maniculatus allowed access, but birds, insects, and small mammals larger than $P$. maniculatus excluded, no seeds added). Cages were made of wood frames forming blocks of three $45 \times 45 \times 9 \mathrm{~cm}$ cells covered with a 1-cm-mesh screen. Each cell in a block was randomly assigned to control, no predation, or mouse-predation treatments. Cells assigned to mouse predation and control cells were drilled with six 3-cm-diameter holes located $\sim 4.0 \mathrm{~cm}$ from the bottom and evenly spaced on two opposite sides to provide mouse access. Cages were dug into the ground $\sim 2 \mathrm{~cm}$ deep and secured by pounding wooden stakes into the ground at the four corners and connecting the stakes with wire across the top of the cage. Tanglefoot was applied to the outer bottom edge of each cage near ground level to reduce access by granivorous insects. One hundred seeds of each species obtained from a commercial distributor within the region (Sunmark Seeds International, Troutdale, Oregon, USA) were scattered in each predation and no-predation cell. Seeds were added in June when $B$. sagittata and $P$. spicata naturally disperse their seeds. No seeds were added to the control cell, which allowed us to account for natural-seed-rain, seed-bank, and cage effects. Seedling emergence and establishment cages were set out along four secondary transects running parallel to and $10 \mathrm{~m}$ from the primary transects (Appendix). Six cages were set out $40 \mathrm{~m}$ apart along each of these transects so that three cages were on each side of the herbicide-treatment boundary. The innermost cages were $20 \mathrm{~m}$ from the treatment boundary. This resulted in 24 cages per plot. Cages were checked periodically for seedling emergence starting in March and continuing until seedling emergence ended in April or May. This experiment was first initiated in spring 2001 (Fig. 1). In spring 2002 all seedlings were quantified and removed and new seeds were added to repeat the experiment. In spring 2003 seedlings were counted, but left to grow in order to examine establishment into the population in 2004. Establishment was quantified in the spring of 2004 by counting all surviving seedlings at that time. Data were excluded for cages that showed signs of physical disturbance. 

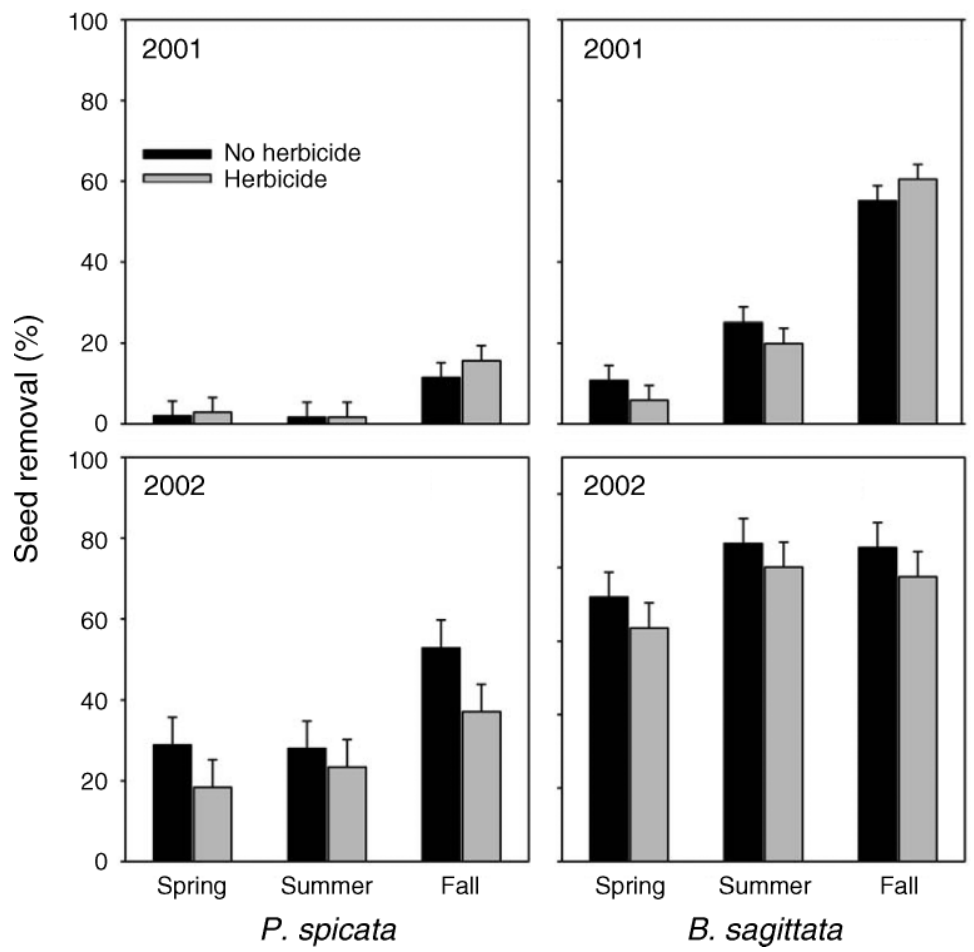

FIG. 2. Percentage (mean and SE) of Pseudoroegneria spicata and Balsamorhiza sagittata seeds removed from cups by Peromyscus maniculatus in spring, summer, and fall of 2001 and 2002 in herbicide-treated and untreated-control plots. Initial seed offerings were $10.0 \mathrm{~g}$ dry mass per station.

\section{Data analyses}

Seed-removal rates were compared separately for each year using mixed-effects linear models in the PROC MIXED procedure (SAS Institute 1999) where replicate plot was treated as a random factor and herbicide treatment, seed type, and season were treated as fixed factors within a repeated-measures design. The cage was the basic sample unit that was repeated across seasons. Mouse abundance was added as a covariate to assess the effect of $P$. maniculatus abundance on seed predation by summing the number of unique mice captured within one trap station of each seed depot during each sample period. Seedling-emergence rates were not normally distributed, so these data were analyzed with the PROC GENMOD procedure using a Poisson distribution scaled for over-dispersed data (SAS Institute 1999). Peromyscus maniculatus treatment (deer mouse access or no access), herbicide treatment, and seed type were treated as fixed factors, replicate plot was treated as a random factor, and the control cage, which controlled for cage effects, background seed rain, and seed-bank effects on seedling emergence was included as a covariate. Each year was analyzed separately.

\section{RESUlts \\ Seed removal}

Seedling-removal experiments indicated that deer mice (Peromyscus maniculatus) selected for larger seeds and seed removal rates correlated with $P$. maniculatus abundance. In 2001 P. maniculatus populations were relatively low and just beginning to decline on herbicidetreatment plots in response to Centaurea maculosa and Urophora removal (Fig. 1; Pearson and Fletcher 2008). During this period, seed-removal rates were relatively low (Fig. 2) and did not differ between herbicide treatments and controls $\left(F_{1,91}<0.01, P=0.98\right)$. However, seed removal rates were significantly higher for Balsamorhiza sagittata than for Pseudoroegneria spicata $\left(F_{1,94}=318.56\right.$, $P<0.01)$ and removal rates increased from spring to fall $\left(F_{2,188}=122.78, P<0.01\right)$. This seasonal increase in seedremoval rates occurred for both plant species, but was much stronger for $B$. sagittata than for $P$. spicata as indicated by the significant seed type $\times$ season interaction $\left(F_{1,176}=64.98, P<0.01\right)$. These patterns were not altered by the herbicide treatment; there was no significant interaction for herbicide treatment $\times$ seed type $\left(F_{1,94}=\right.$ 1.59, $P=0.21)$, herbicide treatment $\times$ season $\left(F_{2,188}=\right.$ 2.07, $P=0.13)$, or herbicide treatment $\times$ seed type $\times$ season $\left(F_{2,176}=0.63, P=0.54\right)$. Peromyscus maniculatus abundance was significantly correlated with seed-removal rates when added as a covariate to the full model $\left(F_{1,457}=\right.$ 15.53, $P<0.01)$.

In 2002, when $P$. maniculatus populations were higher and the mice showed stronger declines on herbicidetreatment plots relative to controls (Fig. 1), seed-removal rates were significantly lower in the herbicide treatment plots compared to control plots $\left(F_{1,91}=15.11, P<0.01\right.$; 

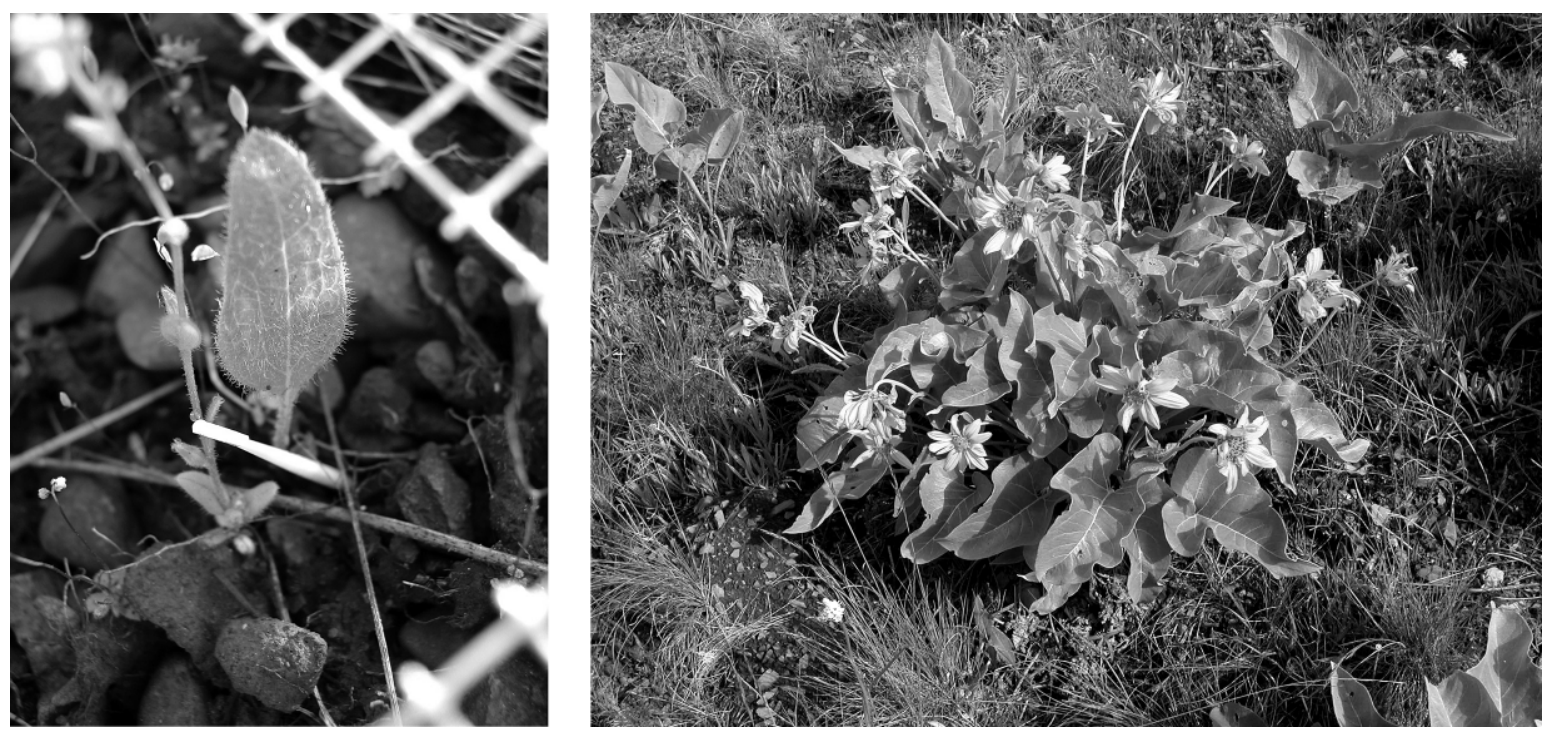

Plate 1. (Left) Arrowleaf balsamroot (Balsamorhiza sagittata) seedling viewed from the top of a rodent-proof seed cage, where it survived postdispersal seed predation by deer mice (Peromyscus maniculatus). (Right) Adult balsamroot plant in flower. Photo credits: D. E. Pearson.

Fig. 2). As in the previous year, there were greater removal rates of $B$. sagittata seeds than $P$. spicata seeds $\left(F_{1,94}=436.54, P<0.01\right)$, and seed removal increased from spring to fall for both species $\left(F_{2,188}=19.97, P<\right.$ $0.01)$. However, the seasonal increase in removal rates was weaker for $B$. sagittata than $P$. spicata as reflected by the significant seed type $\times$ season interaction $\left(F_{2,187}=\right.$ 7.62, $P<0.01)$. Relative to $P$. spicata, B. sagittata removal started very high and leveled off very quickly. This leveling off of $B$. sagittata seed removal was partly because deer mouse predation on $B$. sagittata was so intense by summer and fall that mice were emptying seed dishes, despite our efforts to avoid this problem by conducting pilot work to establish appropriate seed quantities. As in 2001, none of the observed patterns in seed removal were altered by herbicide treatment, as indicated by the lack of significant interactions for herbicide treatment $\times$ season $\left(F_{2,188}=0.67, P=0.51\right)$, herbicide treatment $\times$ seed type $\left(F_{1,94}=0.38, P=0.54\right)$, and herbicide treatment $\times$ seed type $\times$ season $\left(F_{2,187}=\right.$ $0.41, P=0.67)$. Mouse abundance was significantly correlated with seed-removal rates when added to the model as a covariate $\left(F_{1,468}=13.67, P<0.01\right)$.

\section{Seedling emergence}

During the period when the 2002 seedling-emergence cohort was out, P. maniculatus population levels were moderate and mice had just begun to decline on the herbicide treatment plots relative to the controls (Fig. 1). Nonetheless, seedling emergence results in 2002 indicated that exposing seeds to deer mouse predation significantly reduced seedling emergence of both species $\left(\chi^{2}=9.20, \mathrm{df}=1, P<0.01\right.$; Fig. 3$)$, with mice having a stronger effect on the larger-seeded $B$. sagittata, as indicated by the $P$. maniculatus treatment $\times$ seed type interaction $\left(\chi^{2}=7.93, \mathrm{df}=1, P<0.01\right)$. These patterns occurred despite higher overall seedling emergence for $P$. spicata than $B$. sagittata in this year $\left(\chi^{2}=16.18, \mathrm{df}=\right.$ $1, P<0.01)$. Herbicide had no direct effect on overall seedling emergence rates $\left(\chi^{2}=1.19, \mathrm{df}=1, P=0.28\right)$ or emergence rates by species (herbicide $\times$ seed type; $\chi^{2}=$ 0.77 , df $=1, P=0.38$ ), and herbicide did not indirectly alter deer mouse effects on seedling emergence rates; there was no significant $P$. maniculatus $\times$ herbicide interaction $\left(\chi^{2}=0.76, \mathrm{df}=1, P=0.38\right)$ and no significant $P$. maniculatus $\times$ herbicide $\times$ seed type interaction $\left(\chi^{2}=\right.$ 0.12 , df $=1, P=0.73)$. The control-cage covariate was significant $\left(\chi^{2}=6.85, \mathrm{df}=1, P<0.01\right)$, but little seedling emergence was observed in the control cages relative to seed additions.

Peromyscus maniculatus impacts on seedling emergence in 2003 were much stronger than in 2002 (Fig. 3). Notably, during the period when mice had access to seeds that germinated in spring 2003 (i.e., the period from spring 2002 to spring 2003), mouse populations were substantially higher than in the previous year, and mice were about half as abundant on the herbicidetreatment plots (Fig. 1). During this period, $P$. maniculatus reduced seedling emergence of both species $\left(\chi^{2}=7.76, \mathrm{df}=1, P<0.01 ;\right.$ Fig. 3) with much stronger effects on $B$. sagittata as indicated by the $P$. maniculatus treatment $\times$ seed type interaction $\left(\chi^{2}=5.91, \mathrm{df}=1, P=\right.$ 0.02). In contrast to 2002 , in 2003 B. sagittata seedling emergence tended to be higher than $P$. spicata seedling emergence $\left(\chi^{2}=2.10\right.$, $\left.\mathrm{df}=1, P=0.15\right)$, but this was mostly due to higher $B$. sagittata seedling emergence in cages that precluded mouse access (Fig. 3). As in 2002, herbicide had no direct effect on overall seedling 

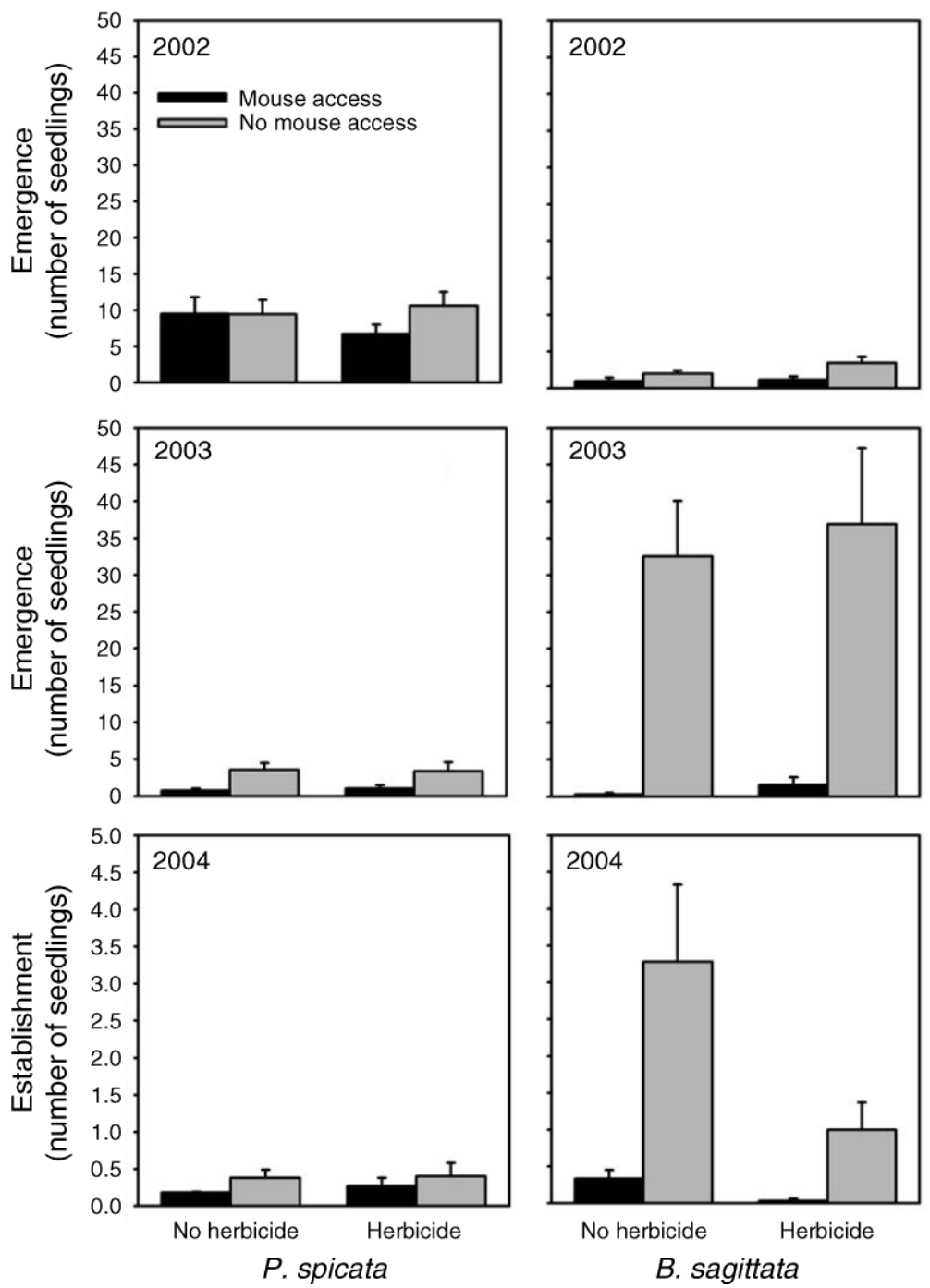

FIG. 3. Number (mean and SE) of Pseudoroegneria spicata and Balsam sagittata seedlings that germinated in 2002 and 2003 and established as first-year seedlings in 2004 on herbicide-treatment plots and untreated controls, in the presence or absence of deer mice. The initial number of seeds was 100 seeds per species per cage. Note that the scales differ between seedling emergence (in 2002 and 2003) and seedling recruitment (establishment in 2004). The data presented are not transformed.

emergence rates $\left(\chi^{2}=1.41\right.$, df $\left.=1, P=0.23\right)$ or emergence rates by species (herbicide $\times$ seed type; $\chi^{2}=$ $1.85, \mathrm{df}=1, P=0.17)$. However, there was evidence that herbicide reduced negative effects of mice on seedling emergence ( $P$. maniculatus $\times$ herbicide, $\chi^{2}=3.24, \mathrm{df}=1$, $P=0.07)$ by reducing mouse abundance and seed predation. There was no significant $P$. maniculatus treatment $\times$ herbicide treatment $\times$ seed type interaction $\left(\chi^{2}=1.07, \mathrm{df}=1, P=0.30\right)$. The control-cage covariate was not significant $\left(\chi^{2}=0.90, \mathrm{df}=1, P=0.34\right)$, and little seedling emergence was observed in the control cages relative to seed additions.

\section{Seedling establishment}

Establishment of seedlings from 2003 to 2004 generally followed the patterns we observed for seedling emergence in 2003 (Fig. 3). Peromyscus maniculatus access to seeds significantly reduced seedling establishment $\left(\chi^{2}=12.00, \mathrm{df}=1, P<0.01\right)$ with a stronger effect on B. sagittata than on P. spicata (Fig. 3) as indicated by a $P$. maniculatus treatment $\times$ seed type interaction $\left(\chi^{2}=\right.$ $12.50, \mathrm{df}=1, P<0.01)$. Seedling establishment overall did not differ between species $\left(\chi^{2}=0.87, \mathrm{df}=1, P=\right.$ 0.35 ). Herbicide suppressed overall seedling establishment $\left(\chi^{2}=4.23\right.$, df $\left.=1, P=0.04\right)$, but the herbicide mainly reduced establishment of the forb B. sagittata (Fig. 3), while P. spicata establishment appeared slightly higher in the herbicide treatment. However, the herbicide $\times$ seed type interaction was only marginally significant $\left(\chi^{2}=3.07, \mathrm{df}=1, P=0.08\right)$. Herbicide did not alter mouse effects on seedling establishment as indicated by the nonsignificant $P$. maniculatus $\times$ 
herbicide treatment interaction $\left(\chi^{2}=0.47, \mathrm{df}=1, P=\right.$ 0.49 ). The $P$. maniculatus treatment $\times$ seed type $\times$ herbicide treatment interaction was not significant $\left(\chi^{2}=\right.$ 2.14 , $\mathrm{df}=1, P=0.14)$. However, there appeared to be an interaction between herbicide and mouse effects on $B$. sagittata that did not affect $P$. spicata (Fig. 3). Removing $P$. spicata from the model confirmed that herbicide suppression of $C$. maculosa indirectly reduced the effect of mouse seed predation on B. sagittata $(P$. maniculatus $\times$ herbicide effect, $\chi^{2}=3.70$, $\mathrm{df}=1, P=$ $0.05)$. The control cage covariate was not significant $\left(\chi^{2}=1.87, \mathrm{df}=1, P=0.17\right)$, and much lower establishment occurred in control cages than in cages with seed additions.

\section{DisCUSSION}

Growing evidence suggests that many plant populations are seed limited (Turnbull et al. 2000, Clark et al. 2007, Poulsen et al. 2007) and predispersal and postdispersal seed predation can reduce seedling recruitment (Louda and Potvin 1995, Maron and Simms 2001, Cummings and Alexander 2002, Herrera et al. 2002, Amsberry and Maron 2006). A few studies have shown how such reductions in recruitment caused by seed predation can ultimately affect plant populations (e.g., Edwards and Crawley 1989, Louda and Potvin 1995, Maron and Kauffman 2006). However, we know little about how seed-predator abundance and the factors affecting seed predator abundance influence these outcomes, particularly as they relate to exotic-plant invasions and invasive-species management. Through a large-scale experimental manipulation, we showed that trophic linkages in a broader community context may determine the impact of seed predation on plant populations. Specifically, we found that alternative food resources increased the abundance of an omnivorous seed predator, which increased seed predation rates and decreased plant recruitment. Our results suggest that Urophora biocontrol insects may exacerbate the negative impacts of Centaurea maculosa on native plants by increasing Peromyscus maniculatus (deer mouse) populations and deer mouse seed predation on native plants in a form of tri-trophic or second-order apparent competition (Fig. 4). These results also suggest that broadleaf herbicide applications targeting C. maculosa suppression may negate this apparent competition by removing the biocontrol food subsidy and reducing mouse seed predation on native plants. However, the direct negative herbicide effects on native-forb seedling establishment may counter the positive indirect release effect from reducing seed predation.

\section{Seed removal}

Seed-removal experiments established that P. maniculatus are selective predators of native-plant seeds in this system. Seed removal by $P$. maniculatus was $\sim 2-20$ times higher for the larger-seeded Balsamorhiza sagittata than the smaller-seeded Pseudoroegneria spicata, indi-

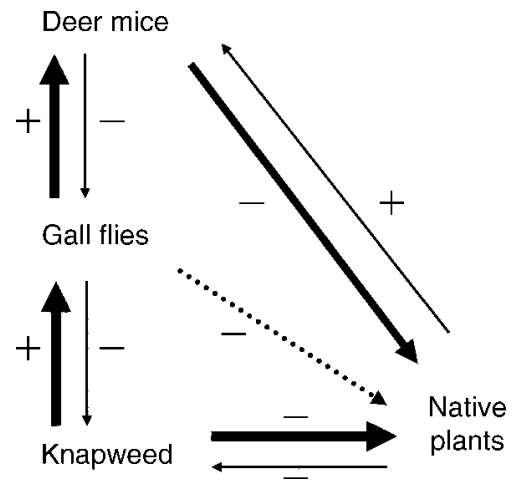

FIG. 4. Community-interaction diagram showing direct and indirect interactions between spotted knapweed (Centaurea maculosa), gall flies (Uphora spp.), deer mice (Peromyscus maniculatus), and native plants. Parameterization of interactions (described in the text) indicates that, in addition to its direct negative effects on native plants, spotted knapweed also has indirect negative effects on native plants that are facilitated by gall fly food subsidies to deer mice that consume seeds and suppress recruitment of large-seeded native plants in a form of second-order apparent competition. The dotted line represents the potential for direct negative effects of biocontrol agents on nontarget plants that are screened against in host-specificity testing. In this system, gall flies are host-specific and do not attack nontarget plants. Arrows indicate the direction of interactions, and arrow thickness indicates the relative strength of the interactions. Signs indicate whether the interaction is positive or negative.

cating that deer mice can be an important seed predator in intermountain grasslands. The observed selection for larger seeds is consistent with size-dependent seed selection documented for small-mammal seed predators elsewhere (Mittelbach and Gross 1984, Brown and Heske 1990, Hulme 1994a, Garb et al. 2000) and has significant implications for the role of deer mice in influencing plant community composition (e.g., Brown and Heske 1990).

Seed removal was variable, as reported by other authors (Hulme 1994b, Maron and Simms 1997, Manson and Stiles 1998), but this variability was attributable to fluctuations in mouse abundance. Seedremoval rates increased from spring to fall and from the first year to the second year, which corresponded with seasonal and annual increases in P. maniculatus populations. Other studies evaluating small-mammal abundance in relation to seed predation have shown similar correlations (Ostfeld et al. 1997, Kelt et al. 2004). Our results suggest that the intensity of small-mammal seed predation is largely a density-driven process, indicating that factors affecting deer mouse density are likely to determine the effects of this predator on plant communities. The herbicide treatment supports this conclusion. There was no difference in seed-removal rates between the herbicide treatment and control in 2001 when mouse abundance was low and $P$. maniculatus were just beginning to respond to experimental treatments. By 2002, mouse populations were higher, and herbicide 
removal of C. maculosa and the Urophora food resource had clearly reduced deer mouse populations on herbicide-treated plots relative to the controls (see Pearson and Fletcher 2008). Consistent with these changes in deer mouse abundance, seed-removal rates were significantly lower on the treatment plots in 2002.

\section{Seedling emergence}

Seed predation does not always translate into population-level effects on plants, because seed predation may be largely compensatory if plants are safe-site limited rather than seed limited (Harper 1977, Crawley 1992, Maron and Gardner 2000, Clark et al. 2007, Poulsen et al. 2007). Therefore, evaluating whether seed predation translates into a reduction in seedling establishment is crucial (see Louda 1983, Maron and Simms 2001). By examining seedling emergence and establishment rates where $P$. maniculatus were either allowed or precluded access to seed-addition plots, we evaluated the effect of seed predation on recruitment of $B$. sagittata and $P$. spicata. Seed-addition experiments established that both species were highly seed limited (see Clark et al. 2007), as seed addition increased emergence rates by $50-85 \%$ for $P$. spicata and $82-99 \%$ for $B$. sagittata in the absence of herbicide and $P$. maniculatus predation. Deer mouse seed predation reduced seedling emergence for both species as indicated by lower emergence rates when mice were allowed access to seeds. Additionally, the selection exhibited by $P$. maniculatus for B. sagittata seeds in the seed-offering experiments was also reflected in seedling-emergence experiments. Mice reduced seedling emergence for $B$. sagittata by $52-99 \%$ and for P. spicata by $0-78 \%$. These patterns held for both years, despite substantial differences in seedling-emergence rates for both species between years. The effect of mouse abundance on seed-removal rates observed in seed-offering experiments was also reflected in the seedling-emergence results. Mouse-related reductions in seedling emergence were much stronger in the second year when mouse populations were higher, particularly for B. sagittata. Moreover, reducing mouse populations through an herbicide that suppressed C. maculosa and the Urophora food subsidy tended to reduce the effect of mice on seedling emergence, an effect that was stronger for seedling establishment.

\section{Seedling establishment}

Peromyscus maniculatus seed predation significantly reduced seedling establishment, and selection for larger seeds resulted in greater reductions in seedling establishment of B. sagittata than P. spicata one year after emergence (90-97\% reductions in B. sagittata vs. 33$53 \%$ reductions in $P$. spicata seedling establishment). One major difference between results from the seedling establishment and emergence experiments was that the herbicide exhibited direct phytotoxic effects on seedling establishment not observed in the emergence experi- ments. The herbicide's phytotoxic effects reduced seedling establishment even though it did not affect emergence. These direct effects on seedlings appeared to differ by species; $B$ sagittata establishment was suppressed by herbicide but $P$. spicata was not. Although the interaction between herbicide and seed species was only marginally significant, these results are consistent with expectations for the broadleaf herbicide, picloram, which suppresses forbs but releases grasses and is known to suppress B. sagittata seedlings (Rice et al. 1997, Rice and Toney 1998; Y. K. Ortega and D. E. Pearson, unpublished manuscript). The lack of direct effects of herbicide on seedling emergence in 2002 and 2003 given the later effect on establishment in 2004 suggests that the herbicide does not inhibit germination or emergence but it does affect establishment as seedlings continue to develop. These results indicate that picloram effects on nontarget native-forb seedlings may persist for up to four years following treatment, at least in dry habitats such as those at Calf Creek (western Montana, USA) where herbicide is not rapidly leached by precipitation.

\section{Peromyscus maniculatus and management of Centaurea maculosa}

Our experiments indicated that (1) P. maniculatus is an important seed predator that may influence plant composition in intermountain grasslands and (2) consumer density is a key determinant of the strength of seed-predator impacts. These results have important implications for exotic-plant invasions and their management in this system. Although we did not evaluate $P$. maniculatus predation on $C$. maculosa seeds in this study, prior work has demonstrated that deer mice avoid consuming C. maculosa seeds. Stomach contents of deer mice collected in $C$. maculosa-invaded habitats were virtually devoid of $C$. maculosa seeds even though the mice examined were actively foraging on Urophora larvae within $C$. maculosa seedheads (Pearson et al. 2000). Moreover, C. maculosa is a prolific seed producer that, unlike dominant native plants in this system, is not seed limited and appears little affected by intensive seed predator attacks (Maddox 1982, Stanley 2005). Therefore, seed predation by $P$. maniculatus may facilitate $C$. maculosa invasion by suppressing native plant but not $C$. maculosa recruitment. This situation may be further exacerbated because Urophora biocontrol agents introduced to control C. maculosa subsidize and elevate deer mouse populations (Ortega et al. 2004, Pearson and Callaway 2006, Pearson and Fletcher 2008). Thus, while C. maculosa directly impacts native plants through competition, it may also indirectly impact them through Urophora food subsidies to a native seed predator in a form of tri-trophic or second-order apparent competition. This interaction pathway, originally postulated by Pearson and Callaway (2003), can now be parameterized using results from this and other studies (see Fig. 4).

The direct negative effect of $C$. maculosa on most native plants is quite strong (Ridenour and Callaway 
2003, Ortega and Pearson 2005), but is reciprocated by a weak negative effect of native plants on C. maculosa (e.g., Ridenour and Callaway 2003). Centaurea maculosa has a very strong positive effect on Urophora (Myers and Harris 1980), which in turn have a very weak negative effect on C. maculosa (Maddox 1982, Stanley 2005). Urophora have a strong positive effect on deer mice (Ortega et al. 2004, Pearson and Callaway 2006, Pearson and Fletcher 2008), but deer mice reciprocate with a weak negative effect on Urophora (Stanley 2005). Finally, our present study shows that deer mouse seed predation can have strong negative effects on native plants, which presumably provide some positive effect on deer mice as a food resource. Collectively, these interactions suggest that the Urophora biological control agents introduced to release native plants from the direct negative impacts of C. maculosa may instead facilitate indirect negative effects on native plants through foodweb interactions. Our overall experimental results manipulating the full interaction chain from C. maculosa to Uropohra to P. maniculatus to native plants support this hypothesis, at least for the larger seeded B. sagittata.

These results have important implications for the management of invasive plants. With regard to biological control, the second-order apparent competition identified here is novel. In the classical biological control of plants, prospective biocontrol agents are carefully screened for host specificity to prevent agents from directly impacting nontarget plant species in the introduced range (McEvoy 1996, Hajek 2004). However, as our results show, host-specificity does not prevent agents from indirectly impacting native plants. In the $>30$ years since their introduction, Urophora have not been known to attack any nontarget species. Yet, Urophora appear to indirectly impact native plants by subsidizing native, generalist consumers that feed on native-plant seeds. This amounts to the biocontrol increasing the negative impact of the invader on native species that it was introduced to help. Arguably, the strength of this interaction chain from C. maculosa to native plants would diminish if the biocontrol agent effectively suppressed C. maculosa, thereby creating a negative feedback on its own populations (Pearson and Callaway 2003). Thus, our results reemphasize the importance of biocontrol efficacy to ensure safe and effective biological control (Pearson and Callaway 2003, 2005, 2006, Thomas and Reid 2007).

Broadleaf herbicide appears to mitigate some effects of C. maculosa and its exotic biological-control agent but not all. Herbicide suppressed C. maculosa on our study site (Pearson and Fletcher 2008) consistent with other studies (Rice et al. 1997, Rice and Toney 1998, Pearson and Fletcher 2008; Y. K. Ortega and D. E. Pearson, unpublished data), but suppressing the target weed does not always ensure native plants will be released from the negative effects of invaders like $C$. maculosa (Y. K. Ortega and D. E. Pearson, unpublished manuscript). Herbicide appeared to restore deer mouse populations elevated by the Urophora biocontrol food subsidies (Pearson and Fletcher 2008), which likely has numerous positive indirect effects. For instance, Urophora subsidies have been shown to elevate Sin Nombre virus, the etiologic agent for hantavirus pulmonary syndrome in humans, by elevating deer moouse densities (Pearson and Callaway 2006). Thus, reducing $P$. maniculatus populations likely reduced the virus on the landscape, though this was not tested. We found that herbicide indirectly moderated the impacts of seed predation on native plants by reducing deer mouse populations. However, the direct negative effects of the broadleaf herbicide on native-forb seedlings appeared to outweigh its indirect benefits, at least in the short term, as few seedlings survived the herbicide. The long-term outcome of such effects will largely depend on the success of applying herbicide to invaded intermountain prairie. If herbicide controls the weed with one application, the direct negative effect of herbicide will subside while its positive effects of eliminating $C$. maculosa persist. However, it appears that picloram must be repeatedly applied for long-term C. maculosa control (Rice et al. 1997), and therefore careful timing of herbicide applications is crucial to minimizing nontarget effects (Y. K. Ortega and D. E. Pearson, unpublished manuscript).

Our results illustrate the importance of understanding how consumer and other community interactions may affect invasion and emphasize the need to expand such understandings to improve invasive-species management.

\section{ACKNOWLEDGMENTS}

Kerry Foresman, John Maron, Yvette Ortega, Len Ruggiero, and Diana Six provided comments on this manuscript. Rudy King consulted on statistical analyses. Mike Thompson graciously provided access to Calf Creek. Cindy Adams, Shanon Connolly, Julie Miller, Todd Musci, and Kathryn Socie assisted in collecting field data. This work was funded by NSF SGER-010889, DEB-9726829, DoD SERDP, and the Rocky Mountain Research Station, and Bitterroot Ecosystem Management Research Project, USDA Forest Service.

\section{Literature Cited}

Amsberry, L. K., and J. L. Maron. 2006. Effects of herbivore identity on plant fecundity. Plant Ecology 187:39-48.

Bowers, M. A., and H. D. Smith. 1979. Differential habitat utilization by sexes of the deermouse, Peromyscus maniculatus. Ecology 60:869-875.

Brown, J. H., and E. J. Heske. 1990. Control of a desertgrassland transition by a keystone rodent guild. Science 250 : $1705-1707$.

Clark, C. J., J. R. Poulsen, D. J. Levey, and C. W. Osenberg. 2007. Are plant populations seed limited? A critique and meta-analysis of seed addition experiments. American Naturalist 170:128-142.

Crawley, M. J. 1992. Seed predators and plant population dynamics. Pages 157-192 in M. Fenner, editor. Seeds, the ecology of regeneration in plant communities. CAB International. Wallingford, UK.

Cummings, C. L., and H. M. Alexander. 2002. Population ecology of wild sunflower: effects of seed density and postdispersal vertebrate seed predators. Oecologia 130:274-280. 
Edwards, G. R., and M. J. Crawley. 1999. Rodent seed predation and seedling recruitment in mesic grassland. Oecologia 118:288-296.

Elton, C. S. 1958. The ecology of invasions by animals and plants. Methuen, London, UK.

Follett, P. A., and J. J. Duan. 2000. Nontarget effects of biological control. Kluwer Academic Publishers, Boston, Massachusetts, USA.

Garb, J., B. P. Kotler, and J. S. Brown. 2000. Foraging and community consequences of seed size for coexisting Negev Desert granivores. Oikos 88:291-300.

Gurr, G., and S. Wratten. 2000. Biological control: measures of success. Kluwer Academic Publishers, Boston, Massachusetts, USA.

Gutierrez, J. R., P. L. Meserve, S. Herrera, L. C. Contreras, and F. M. Jaksic. 1997. Effects of small mammals and vertebrate predators on vegetation in the Chilean semiarid zone. Oecologia 109:398-406.

Hajek, A. E. 2004. Natural enemies: an introduction to biological control. Cambridge University Press, Cambridge, UK.

Harper, J. L. 1977. Population biology of plants. Academic Press, London, UK.

Herrera, C. M., M. Medrano, P. J. Rey, M. Sanchez-Lafuente, M. B. Garcia, J. Guitian, and A. J. Manzaneda. 2002. Interaction of pollinators and herbivores on plant fitness suggests a pathway for correlated evolution of mutualismand antagonism-related traits. Proceedings of the National Academy of Sciences (USA) 99:16823-16828.

Holt, R. D. 1977. Predation, apparent competition, and the structure of prey communities. Theoretical Population Biology 12:197-229.

Howe, H. F., B. Zorn-Arnold, A. Sullivan, and J. S. Brown. 2006. Massive and distinctive effects of meadow voles on grassland vegetation. Ecology 87:3007-3013.

Hulme, P. E. 1994a. Seedling herbivory in grassland: relative impact of vertebrate and invertebrate herbivores. Journal of Ecology 82:873-880.

Hulme, P. E. 1994b. Post-dispersal seed predation in grassland: its magnitude and sources of variation. Journal of Ecology 82:645-652.

Hulme, P. E. 1996. Herbivores and the performance of grassland plants: a comparison of arthropod, mollusc and rodent herbivory. Journal of Ecology 84:43-51.

Huntly, N., and R. Inouye. 1988. Pocket gophers in ecosystems: patterns and mechanisms. BioScience 38:786-793.

Keane, R. M., and M. J. Crawley. 2002. Exotic plant invasions and the enemy release hypothesis. Trends in Ecology and Evolution 4:164-170.

Kelt, D. A., P. L. Meserve, L. K. Nabors, M. L. Forister, and J. R. Gutierrez. 2004. Foraging ecology of small mammals in semiarid Chile: the interplay of biotic and abiotic effects. Ecology 85:383-397.

Klironomos, J. N. 2002. Feedback with soil biota contributes to plant rarity and invasiveness in communities. Nature 417: 67-70.

Lang, R. F., R. D. Richard, P. E. Parker, and L. Wendel. 2000. Release and establishment of diffuse and knapweed biocontrol agents by USDA, APHIS, PPQ, in the United States. Pan-Pacific Entomology 76:197-218.

Louda, S. M. 1983. Seed predation and seedling mortality in the recruitment of a shrub, Haplopappus venetus (Asteraceae), along a climatic gradient. Ecology 64:511-521.

Louda, S. M., and M. A. Potvin. 1995. Effects of inflorescencefeeding insects on the demography and lifetime fitness of a native plant. Ecology 76:229-245.

Lynche, D. 1955. Ecology of the aspen groveland in Glacier County, Montana. Ecological Monographs 25:321-344.

Maddox, D. M. 1982. Biological control of diffuse knapweed (Centaurea diffusa) and spotted knapweed (Centaurea maculosa). Weed Science 30:76-82.
Manson, R. H., R. S. Ostfeld, and C. D. Canham. 2001. Longterm effects of rodent herbivores on tree invasion dynamics along forest-field edges. Ecology 82:3320-3329.

Manson, R. H., and E. W. Stiles. 1998. Links between microhabitat preferences and seed predation by small mammals in old fields. Oikos 82:37-50.

Maron, J. L., and S. N. Gardner. 2000. Consumer pressure, seed versus safe-site limitation, and plant population dynamics. Oecologia 124:260-269.

Maron, J. L., and M. J. Kauffman. 2006. Habitat-specific impacts of multiple consumers on plant population dynamics. Ecology 87:113-124.

Maron, J. L., and E. L. Simms. 1997. Effect of seed predation on seed bank size in seedling recruitment of bush lupine (Lupinus arboreus). Oecologia 111:76-83.

Maron, J. L., and E. L. Simms. 2001. Rodent-limited establishment of bush lupine: field experiments on the cumulative effect of granivory. Journal of Ecology 89:578-588.

McEvoy, P. B. 1996. Host specificity and biological pest control. BioScience 46:401-405.

Mittelbach, G. G., and K. L. Gross. 1984. Experimental studies of seed predation in old-fields. Oecologia 65:7-13.

Mueggler, W. F., and W. L. Stewart. 1980. Grassland and shrubland habitat types of western Montana. General Technical Report INT-66. USDA Forest Service, Ogden, Utah, USA.

Myers, J. H., and P. Harris. 1980. Distribution of Urophora galls in flower heads of diffuse and spotted knapweed in British Columbia. Journal of Applied Ecology 17:359-367.

Noonburg, E. G., and J. E. Byers. 2005. More harm than good: when invader vulnerability to predators enhances impact on native species. Ecology 86:2555-2560.

Ortega, Y. K., and D. E. Pearson. 2005. Weak vs. strong invaders of natural plant communities: assessing invasibility and impact. Ecological Applications 15:651-661.

Ortega, Y. K., D. E. Pearson, and K. S. McKelvey. 2004. Effects of exotic plant invasion and introduced biological control agents on native deer mouse populations. Ecological Applications 14:241-253.

Ostfeld, R. S., R. H. Manson, and C. D. Canham. 1997. Effects of rodents on survival of tree seeds and seedlings in invading old fields. Ecology 78:1531-1542.

Parker, J. D., D. E. Burkepile, and M. E. Hay. 2006. Opposing effects of native and exotic herbivores on plant invasions. Science 311:1459-1461.

Pearson, D. E., and R. M. Callaway. 2003. Indirect effects of host-specific biological control agents. Trends in Ecology and Evolution 18:456-461.

Pearson, D. E., and R. M. Callaway. 2005. Indirect nontarget effects of host-specific biological control agents: implications for biological control. Biological Control 35:288-298.

Pearson, D. E., and R. M. Callaway. 2006. Biological control agents elevate hantavirus by subsidizing mice. Ecology Letters 9:442-449.

Pearson, D. E., and R. J. Fletcher, Jr. 2008. Mitigating exotic impacts: restoring deer mouse populations elevated by an exotic food subsidy. Ecological Applications 18:321-334.

Pearson, D. E., K. S. McKelvey, and L. F. Ruggiero. 2000. Non-target effects of an introduced biological control agent on deer mouse ecology. Oecologia 122:121-128.

Pearson, D. E., Y. K. Ortega, K. S. McKelvey, and L. F. Ruggiero. 2001. Small mammal communities and habitat selection in Northern Rocky Mountain bunchgrass: implications for exotic plant invasions. Northwest Science 75: 107-117.

Poulsen, J. R., C. W. Osenberg, C. J. Clark, D. J. Levey, and B. M. Bolker. 2007. Plants as reef fish: fitting the functional form of seedling recruitment. American Naturalist 170: $168-183$. 
Reinhart, K. O., and R. M. Callaway. 2004. Soil biota facilitate exotic Acer invasion in Europe and North America. Ecological Applications 14:1737-1745.

Rice, P. M., and J. C. Toney. 1998. Exotic weed control treatments for conservation of fescue grassland in Montana. Biological Conservation 85:83-95.

Rice, P. M., J. C. Toney, D. J. Bedunah, and C. E. Carlson. 1997. Elk winter forage enhancement by herbicide control of spotted knapweed. Wildlife Society Bulletin 25:627-633.

Ridenour, W. M., and R. M. Callaway. 2001. The relative importance of allelopathy in interference: the effects of an invasive weed on a native bunchgrass. Oecologia 126: 444-450.

Ridenour, W. M., and R. M. Callaway. 2003. Root herbivores, pathogenic fungi, and competition between Centaurea maculosa and Festuca idahoensis. Plant Ecology 169:161-170.

SAS Institute. 1999. SAS/STAT user's guide, version 8. SAS Institute, Cary, North Carolina, USA.

Seabloom, E. W., and S. A. Richards. 2003. Multiple stable equilibria in grasslands mediated by herbivore population dynamics and foraging behavior. Ecology 84:2891-2904.

Simberloff, D., and P. Stiling. 1996. How risky is biological control? Ecology 77:1965-1974.

Sheley, R. L., J. S. Jacobs, and M. F. Carpinelli. 1998. Distribution, biology, and management of diffuse knapweed (Centaurea diffusa) and spotted knapweed (Centaurea maculosa). Weed Technology 12:353-362.

Stanley, A. G. 2005. Evaluating the effectiveness of biological control: spotted knapweed, seed head gallflies, predacious mice, and environmental variation. Dissertation. University of Washington, Seattle, Washington, USA.

Story, J. M., K. W. Boggs, W. R. Good, L. J. White, and R. M. Nowierski. 1995. Cause and extent of predation on Urophora spp. larvae (Diptera: Tephritidae) in spotted knapweed capitula. Environmental Entomology 24:1467-1472.

Thomas, M. B., and A. M. Reid. 2007. Are exotic natural enemies an effective way of controlling invasive plants? Trends in Ecology and Evolution 22:447-453.

Torchin, M. E., K. D. Lafferty, A. P. Dobson, V. J. McKenzie, and A. M. Kuris. 2003. Introduced species and their missing parasites. Nature 421:628-630.

Turnbull, L. A., M. J. Crawley, and M. Rees. 2000. Are plant populations seed-limited? A review of seed sowing experiments. Oikos 88:225-238.

Tyser, R. W., J. M. Asebrook, R. W. Potter, and L. L. Kurth. 1998. Roadside revegetation in Glacier National Park, U.S.A.: effects of herbicide and seeding treatments. Restoration Ecology 6:197-206.

Vilà, M., and C. M. D'Antonio. 1998. Fruit choice and seed dispersal of invasive vs. noninvasive Carpobrotus (Aizoaceae) in coastal California. Ecology 79:1053-1060.

Vilà, M., and I. Gimeno. 2003. Seed predation of two alien Opuntia species invading Mediterranean communities. Plant Ecology 167:1-8.

Wolfe, L. M. 2002. Why alien invaders succeed: support for the escape-from-enemy hypothesis. American Naturalist 160: 705-711.

\section{APPENDIX}

A figure showing the plot design used in our study (Ecological Archives A018-051-A1). 